\title{
Development of Student Worksheet Based on a Scientific Approach for Rotational Dynamics Concept
}

\author{
Herni Yuniarti Suhendi, Diah Mulhayatiah, Endah \\ Kurnia Yuningsih, Adam Malik, Resy Fauziah \\ UIN Sunan Gunung Djati Bandung \\ Bandung, Indonesia
}

\author{
Ryan Ardiansyah \\ Universitas Siliwangi \\ Tasikmalaya, Indonesia
}

\begin{abstract}
Experience is divided into learning. Student worksheet is used as a medium to train students' critical skills. The research design used is ADDIE approach. The ADDIE stage it uses Analysis, Design, Development, Implementation, and Evaluation. Validation testing of some experts is a way to look at the feasibility of student worksheet and conduct tests (pretestposttest) to determine whether or not improvement of critical thinking skills of learners. The sample used in the research is student first semester of physics education department. Development of student worksheet-based scientific approach gets a good predicate based on expert validation. The data generated from the questionnaire response of learners with a very good score that shows learners happy using student worksheet in the learning process. There is also an increase in critical thinking skills with an increase in $\mathrm{N}$-gain value of 0.61 . It shows the effectiveness in learning process. Based on the results, the development of student worksheet based scientific approach can be an alternative to train the thinking skills.
\end{abstract}

Keywords - student worksheet; ADDIE approach; scientific approach; research development

\section{INTRODUCTION}

Educational paradigm is a way of viewing and understanding education. From this point of view, we observe and understand educational problems and find out how to overcome those problems [1] . Physics is a subject that can foster learners' potential and ability [2]. Based on the basic competencies in lectures, learning objectives cover the development of attitude, knowledge, and skills for each educational unit [3]. The development of skills becomes the focus based on the level of difficulty in achieving it. Regulation of the Minister of Education and Culture number 22 of 2016 explained that skills development is obtained by observing, questioning, experimenting, reasoning, presenting, creating activities. It is supported by the Ministry of Education and Culture in the National Agency for Education Standard [4] based on one of the points stating that the skills that must be developed are Critical-Thinking and Problem-Solving Skills.

In developing higher-order (critical) thinking skills, learners should be actively involved in each activity such as learning through demonstrations, experiments, daily experience or project base using media and process approach [5]. One of the media that can be used is the development of teaching materials as a process of learners' learning activities. One type of teaching materials in the form of text in learning activities is Students Worksheet. Student worksheet should be planned by lecturers of the relevant subject. Lecturers must be careful and have adequate skills in order to produce a quality student worksheet [6], [7]. Therefore, learners can comprehend the basic competencies.

After preliminary study in one of university in Bandung City, the information was obtained through three search objects. First, through interviews with lecturers and learners, it was found that physics is difficult to be taught in accordance with the lecturer's purpose and it is difficult to be understood by learners. Next, through direct observation on learning process, activities only run one way with the lecturer as the center. Last, through critical thinking skills test with the average score of learners' skills $37.80 \%$. Looking at the average of learners' critical thinking indicators achievement that belongs to low to very low category, learners are having difficulty in answering questions that require critical thinking skills.

Based on the above exposure, improvement of learning process-involving learners in developing critical thinking skills is required. One of the efforts in such improvements is the use of developed student worksheet that achieves a feasible to use predicate in the learning process as has been done by some researchers. The development of scientific approach-based student worksheet is one way to develop learners' critical thinking skills. Scientific approach-based student worksheet is a development of student worksheet that focuses on Scientific Approach including observing, questioning, gathering information, associating, and communicating activities [8]. The developed scientific approach-based student worksheet is feasible to be used as one of learning process references in university based on data recapitulation or score given by media expert, which is $79.66 \%$, material expert $81.22 \%$, and learners' response $80.3 \%$ [9]. Students' response after physics lesson using scientific-based module is very positive. The result of response has improved from good category to excellent category.

Several research findings reveal that scientific approachbased student worksheet becomes an alternative to develop learners' critical thinking skills [10]. In line with benefits and 
objectives, the aim of student worksheet is to develop learners' learning independence [11].

\section{RESEARCH METHOD}

This research used research and development method initiated by Robert Maribe Branch. Robert Maribe Branch method developed the design (learning design) using ADDIE approach, which stands for Analysis, Design, Development, Implementation, and Evaluation [12] .

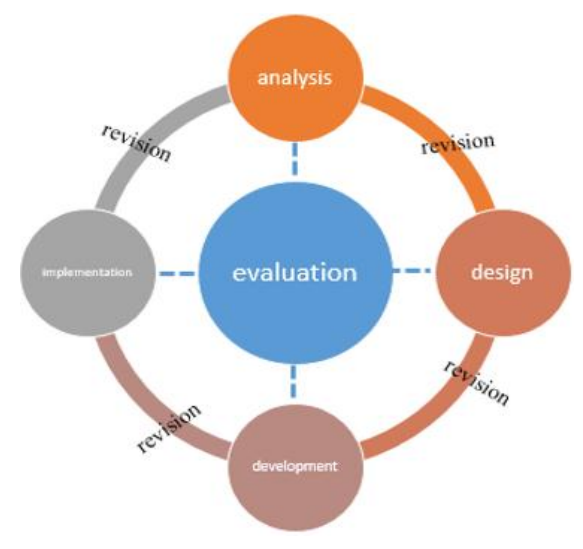

Fig. 1. ADDIE Approach research method for Developing Products

The subject of this research was divided into two, namely for small scale and for large scale [13]. Furthermore, one-group pretest-posttest research design was implemented when using student worksheet in class.

TABLE I. GRUP PRETEST-POSTTEST DESIGN

\begin{tabular}{|l|l|l|l|}
\hline Group & Pretest & Treatment & Posttest \\
\hline $\mathrm{R}$ & $\mathrm{O}_{1}$ & $\mathrm{X}$ & $\mathrm{O}_{2}$ \\
\hline
\end{tabular}

The sample was obtained by using purposive sampling technique. The small-scale sample was 4 chosen students of the universities in Tasikmalaya City and a large-scale sample from one of Bandung's universities.

\section{RESULT AND DISCUSSION}

The results of research using ADDIE method with the stages of Analysis, Design, Development, Implementation, and Evaluation obtained the following results:

\section{A. Analysis}

Analysis is the step of collecting information needs of students in helping the process of effective learning. The step is obtained with three ways of analysis as follows:

\section{1) Analysis of needs}

Learning process cannot be separated from teaching materials as a tool to facilitate the learning process. Commonly used teaching materials, generally come from publishers that are considered good. Seeing this, it cannot have an effective impact on the learning process. The teaching materials are used only as a substitute for lecturers if they cannot teach.
Based on the preliminary study in one of the universities in Bandung City, students' level of critical thinking skills are at a low level. The facts were found by interacting with students and lecturers through interviews, critical thinking skills tests, and observation of the learning process. In the opinion of lecturers, the learning process is still less effective even though it has been using student worksheets from good publishers. This is because the stuffing of student worksheets that do not support the needs of students in the area. The student worksheet contains only items that can be filled by moving the information on the previous page. It does not support the growing skill level of students. In general, the student worksheet should contain activities that not only sharpen students' understanding of concepts, but also sharpen student skills.

Seeing the problems and needs of the research developed the development of instructional materials in the form of student worksheets based on scientific approach. The scientific approach used includes the 5M stage with the aim of training students' skills in developing opinions based on scientific facts.

\section{2) Analysis of curriculum}

The researcher conducted a curriculum analysis at the research site, then found that the university uses the KKNI curriculum. Student competencies that must be achieved are the students must be able to master physics content knowledge in depth, especially on the topics that underlie the study material in high school physics curriculum. While the achievement of learning to be achieved is to master the concept of physics based on natural phenomena that support physics learning in school. After considering the results of curriculum analysis and research time, the subjects taken are basic physics with the material momentum and impulse. In order to achieve the competence and achievement of learning then it must be supported by quality teaching materials. The teaching materials in the form of student worksheet based scientific approach is one of the right solutions.

\section{3) Analysis of student}

Student analysis is characteristic analysis or student background as base of learning device development, which will be compiled. Any process of learning activities is considered as the basis for determining the needs of students in implementing an effective learning process.

Data from the interview result that the students consider physics is a lesson that is quite difficult. Following the learning of physics requires a high concentration to solve the problem of learning. Occasionally the lecturers also try to apply the scientific approach step, but become less effective because of the less active student response. It makes the students only get information sober without developing the skills of thinking. Other facts were also found through tests with indicators of critical thinking skills, obtained data that students' critical thinking skills are in the low category.

The problem can be a little overcome if the scientific approach is not only done directly but also presented in the activity sheet. It aims to keep students in control. Because to create the skills of students need to do exercises that develop skills that are done systematically and procedurally. Teaching materials in the form of student worksheets are given with the 
intention of controlling student activities in training student skills. Student workbooks based on a scientific approach are well suited in an effort to develop student skills by following $5 \mathrm{M}$ steps as an archetype. When the method of discussion is conducted, using the appropriate student worksheet the student is easier to do the discussion by developing their own opinions directed. This is also supported because in the student worksheets based on scientific approach to facilitate each student fill the answer according to his will or the results of thought he gained with direction.

\section{B. Design}

The design stage is the stage of product design or product development that will be used. The product developed in this research is teaching materials that is student-based worksheet scientific approach. The planning stage as below:

a. Preparation design of student worksheet based on scientific approach

1) Preparation of student worksheet needs

2) Preparation of student worksheet framework based on scientific approach

b. Preparation of research instruments

\section{Development}

Development stage is the stage of manufacturing the product by doing the testing steps. The steps of the development of this research include:

\section{1) Development of student worksheets}

Development of student worksheet in this research is development of student worksheet based on scientific approach. Student worksheets created using Corel Draw X6 application. This is done to facilitate placement of component and originality of the product.

\section{2) Validation}

The validation stage is a validation process from content physics experts, media experts, and physics lecturers. The data to be validated are aspects of physics content, presentation, language, and graphics by using criteria scoring scale very well, good, good enough, less good, very less good [15].

Based on the results of validation by the content experts, learning media experts, and physics education lecturer's other departments obtained the results of the assessment of student worksheet based on scientific approach presented in the following table:

TABLE II. ELIGIBILITY CRITERIA FOR STUDENT WORKSHEETS.

\begin{tabular}{|l|l|l|}
\hline \multicolumn{1}{|c|}{$\begin{array}{c}\text { Assessment } \\
\text { Aspect }\end{array}$} & \multicolumn{1}{c|}{ Score } & \multicolumn{1}{c|}{ Criteria } \\
\hline Content & 4,21 & Very good \\
\hline Layout & 4,17 & Good \\
\hline Language & 4 & Good \\
\hline Graph & 4,30 & Very Good \\
\hline
\end{tabular}

\section{Implementation}

Implementation stage in this research is using the material learning in form of student worksheet and the implementation of critical thinking test. The results obtained at this stage include:

\section{1) Small-scale test}

Furthermore, researchers conducted small-scale test data processing. The data obtained on this small-scale test is the average value of students in doing students worksheet based scientific approach. The data obtained as follows

TABLE III. AVERAGE SCORE OF THE STUDENT WORKSHEET SMALLSCALE TEST

\begin{tabular}{|l|l|l|}
\hline $\begin{array}{c}\text { Student } \\
\text { Worksheet } \\
\text { Each meeting }\end{array}$ & Average & percentage \\
\hline 1 & 83,75 & $83,75 \%$ \\
\hline 2 & 87,50 & $87,50 \%$ \\
\hline 3 & 92,50 & $92,50 \%$ \\
\hline
\end{tabular}

\section{2) Large-scale tests}

Secondly, researchers conducted large-scale tests. The data obtained on the large-scale test produces the data in the form of student worksheets of each student. The value is obtained from students with a total of 37 people. Complete can be seen in the following table:

TABLE IV. AVERAGE SCORE OF A LARGE-SCALE STUDENT WORKSHEET TEST

\begin{tabular}{|l|l|l|}
\hline $\begin{array}{c}\text { Student } \\
\text { Worksheet } \\
\text { Each meeting }\end{array}$ & Average & percentage \\
\hline 1 & 81,22 & $81,22 \%$ \\
\hline 2 & 85,27 & $85,27 \%$ \\
\hline 3 & 90,41 & $90,41 \%$ \\
\hline
\end{tabular}

The results obtained from the test obtained the average value of pretest and posttest students. After getting the data then got the value of $\mathrm{N}$-Gain to see the interpretation criteria generated. The complete data can be seen in the table and graph above. The average result of the student worksheet score at the first meeting with the score of 81.22, the student worksheet at the second meeting with the score of 85.27, and the student worksheet of the third meeting with the score of 90.41. If there is an increase in each student worksheet then the student worksheet runs effectively and can be used for lecturing process.

\section{E. Evaluation}

The evaluation stage is the last stage of the development of a student workbook based on a scientific approach. Evaluation is performed after a large-scale test. Meanwhile, at this stage, it will improve the work sheet of the students with suggestions and input after conducting trials on the students on a large scale. The evaluation steps in this research are:

a. Review the concept of physics from various sources in order not to deviate on the theory that should be. 
b. Pay attention to the time it takes to fit the allocations contained in the lesson.

c. Pay attention to the grammar and writing used.

d. Make improvements based on suggestions from various parties of experts as well as learners as users of the student worksheet.

\section{F. Critical thinking skill test}

A critical thinking skill test was conducted to see whether or not the skills were improved after learning using a studentbased scholarly approach to students. The results of critical thinking test obtained an average value of $\mathrm{N}$-gain of 0.6 with a moderate interpretation as shown in the table below:

TABLE V. Pretest-Postest And N-GAin Average Scores

\begin{tabular}{|c|c|c|c|l|}
\hline Information & Pretest & Posttest & $\begin{array}{c}N \text { - } \\
\text { gain }\end{array}$ & Interpretation \\
\hline Sum & 364 & 592 & \multirow{2}{*}{0,50} & medium \\
\hline Average & 45 & 74 & & \\
\hline
\end{tabular}

\begin{tabular}{|c|c|c|c|c|}
\hline \multirow{5}{*}{ 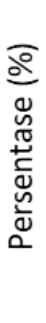 } & \multirow{2}{*}{$\begin{array}{l}80 \\
60\end{array}$} & & 74 & \\
\hline & & 46 & & \\
\hline & 40 & 臣豆谷 & & \\
\hline & 20 & 臣塏 & & 0.5 \\
\hline & & pretes & postes & N-Gain \\
\hline
\end{tabular}

Fig. 2. Average N-Gain Value Graph

Based on the table and graph above, the result showed that there is an increase of the students' critical thinking skill on the rotational dynamics material by using the science-based student-based worksheet with $\mathrm{N}$-Gain 0,50 and the medium interpretation. The acquisition of such average $\mathrm{N}$-gain value, because in every lecture process using the student worksheet cannot be observed periodically at every stage. This is because each individual ability is different so that less maximal gain of $\mathrm{N}$-gain values evenly. According to [16], the learning using the module is done based on individual ability and self-study speed, flexibility, freedom, active participation, supervisory role, interaction with written materials, and instructional.

The improvement of critical thinking skill indicator can be seen in table and figure below:

TABLE VI. THE N-GAIN VALUE OF EACH OF THE CRITICAL THINKING SKILLS INDICATORS

\begin{tabular}{|c|c|c|c|c|c|}
\hline No & Aspect & pre & post & N-Gain & Interpretation \\
\hline 1 & Formulate the question & 52 & 72 & 0,47 & Medium \\
\hline 2 & $\begin{array}{c}\text { Give bases for the } \\
\text { decision }\end{array}$ & 30 & 68 & 0,54 & Medium \\
\hline 3 & Summarizing & 57 & 86 & 0,64 & Medium \\
\hline 4 & Give an example & 53 & 89 & 0,67 & Medium \\
\hline 5 & $\begin{array}{c}\text { Give reasons for a } \\
\text { decision }\end{array}$ & 49 & 77 & 0,42 & Medium \\
\hline 6 & Define Definition & 48 & 72 & 0,42 & Medium \\
\hline
\end{tabular}

\begin{tabular}{|c|c|c|c|c|c|}
\hline No & Aspect & pre & post & N-Gain & Interpretation \\
\hline 7 & $\begin{array}{c}\text { identifying } \\
\text { assumptions }\end{array}$ & 42 & 73 & 0,48 & Medium \\
\hline 8 & analyzing arguments & 33 & 55 & 0,21 & Low \\
\hline \multicolumn{2}{|c|}{ Average } & 45 & 74 & 0,50 & Medium \\
\hline
\end{tabular}

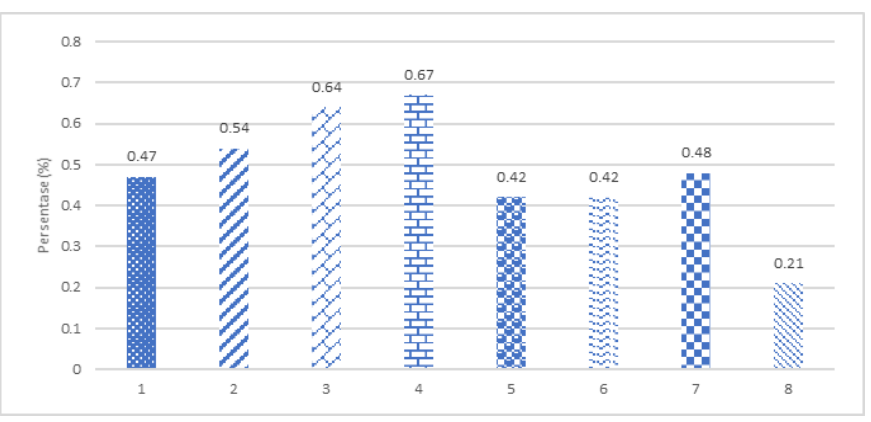

Fig. 3. Graph of N-gain Value of each Critical Thinking Indicator

Based on the table and figure above obtained data that the value of n-gain on each indicator that the largest n-gain of the eight indicators of critical thinking skills is the fourth indicator with a value of n-gain 0.67 on the indicator of the example, the second largest with n-value 0,64 on the third indicator makes the summary, the third largest with a n-gain value of 0.64 gives a simple explanation with either category, n-gain value suggests the hypothesis is 0.48 , the n-gain value formulates the question and makes the definition equal to the value 0,47 and proposed a 0.21 low-gain n-case argument. Of the eight indicators, only one of the lower categorized indicators presents arguments, perhaps this is due to the problem that is quite difficult for students to do.

Based on the student's questionnaire responses analysis, the average value of $80.13 \%$ is obtained with very good criteria if used by students in lecturing process. Suggestion and input based on student response questionnaire obtained positive comments of $81.08 \%$ and $18.92 \%$ gave negative comments. It shows the student worksheets with very good category with high (positive) response can be used in lecturing process [17]. Average and positive response of students with good or very good criteria, then the student worksheet is worthy to be used in lecturing process [18].

\section{CONCLUSION}

Based on the processing and data analysis on the results of research that has been implemented in one of the universities in Bandung about the development of student worksheets based on scientific approach to improve critical thinking skills on the material dynamics of rotation, obtained some conclusions that are: Development of student worksheets based on scientific approach to improve critical thinking skills in rotational dynamics material can be developed using ADDIE approach with analysis, design, development, implementation, and evaluation; The feasibility of developing a student worksheet based on a scientific approach in the process of basic physics lecturing the dynamics of rotation material obtained with very good criteria based on student response and good validator expert; There is an improvement in students' thinking skills 
after being awarded a scientific-based student worksheet based on an increase in $\mathrm{N}$-gain value obtained from pretest-posttest results of 0.50 with medium interpretation.

\section{ACKNOWLEDGEMENT}

Thank to Lembaga Pusat Penelitian dan Pengembangan (LP2M) UIN Sunan Gunung Djati Bandung who has provided funds for the realizations this paper.

\section{REFERENCES}

[1] A. Rusli, "Pendidikan Fisika untuk Abad ke-21: Kesadaran, Wawasan, Kedalaman, Etika (Halaman 16 sd 19)," J. Fis. Indones., vol. 17, no. 50, 2014.

[2] S. Moser, J. Zumbach, and I. Deibl, "The effect of metacognitive training and prompting on learning success in simulation- based physics learning," Sci. Educ., vol. 101, no. 6, pp. 944-967, 2017.

[3] N. R. Council, Education for life and work: Developing transferable knowledge and skills in the 21st century. National Academies Press, 2013.

[4] B. S. N. Pendidikan, "Paradigma Pendidikan Nasional di Abad 21," Jakarta BSNP, 2010.

[5] A. Malik, "Model Problem Solving Laboratory To Improve Comprehension The Concept Of Students," in Proceeding International Seminar on Mathematics, Science, and Computer Science Education (MSCEIS) 2015, 2015, pp. 43-48.

[6] P. Andi, "Panduan kreatif membuat bahan ajar inovatif," Jogjakarta DIVA pres, 2011.

[7] N. Annafi, A. Ashadi, and S. Mulyani, "Pengembangan Lembar Kegiatan Peserta Didik Berbasis Inkuiri Terbimbing Pada Materi Termokimia Kelas XI SMA/MA," INKUIRI J. Pendidik. IPA, vol. 4, no. 3, pp. 21-28, 2015.

[8] L. Kemdikbud, "Kurikulum 2013: Pergeseran paradigma belajar abad21," Jakarta, Juni, 2013.

[9] A. P. P. Sari and A. Lepiyanto, "Pengembangan Lembar Kegiatan Peserta Didik (LKPD) Berbasis Scientific Approach Siswa SMA Kelas X Pada Materi Fungi," BIOEDUKASI (Jurnal Pendidik. Biol., vol. 7, no. 1, 2016.

[10] L. H. Herni Yuniarti Suhendi, Setiya Utari, "PROFIL KEMAMPUAN BERPIKIR KRITIS DAN PENINGKATAN PRESTASI BELAJAR SISWA SMA MELALUI PENERAPAN STRATEGIPROBLEM SOLVING DENGAN READING INFUSION," Gravity J. Ilm. Penelit. dan Pembelajaran Fis., vol. 4, no. 1, 2018.

[11] A. Asnaini, A. Adlim, and M. Mahidin, "Pengembangan Lkpd Berbasis Pendekatan Scientific Untuk Meningkatkan Hasil Belajar Dan Aktivitas Peserta Didik Pada Materi Larutan Penyangga," J. Pendidik. Sains Indones., vol. 4, no. 1, 2016.

[12] Sugiyono, "Metode Penelitian Pengembangan Research and Development," Bandung Alf., 2015.

[13] P. C. Campbell, "Modifying ADDIE: Incorporating new technologies in library instruction," Public Serv. Q., vol. 10, no. 2, pp. 138-149, 2014.

[14] P. Sugiyono, "Metode penelitian kombinasi (mixed methods)," Bandung Alf., 2015.

[15] S. Arikunto, Dasar-dasar evaluasi pendidikan. Bumi Aksara, 2015.

[16] Y. D. Puspitasari, S. Suparmi, and N. S. Aminah, "Pengembangan Modul Fisika Berbasis Scientific Pada Materi Fluida Statis Untuk Meningkatkan Keterampilan Berpikir Kritis," Inkuiri, vol. 4, no. 2, pp. 19-28, 2015.

[17] I. Fitriastuti, N., Sulisworo, D., \& Ishafit, "PENGEMBANGAN MODUL PEMBELAJARAN FISIKA BERBASIS SCIENTIFIC APPROACH PADA MATERI KALOR DAN PERPINDAHANNYA SISWA KELAS VII SMP," Wahana Pendidik. Fis., vol. 3, no. 1, pp. 103-107, 2018.

[18] H. Y. Suhendi, D. Mulhayatiah, and R. Zakwandi, "Effect of Dynamics Rotation Worksheet on Student Critical Thinking Skills Reviewed From IQ Score," Sci. Educ. J. Pendidik. Sains; Vol 7, No 1 June, 2018. 